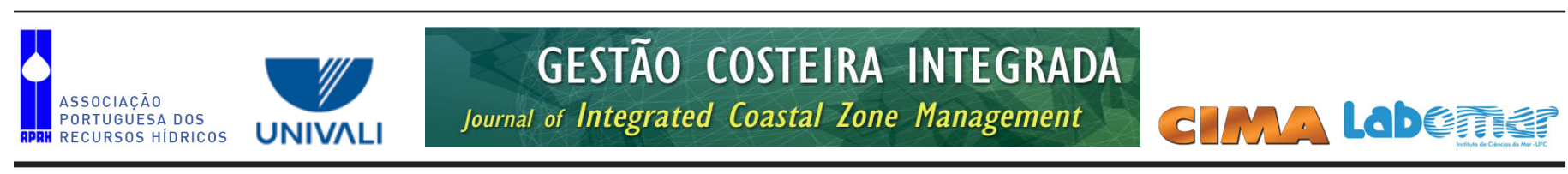

http://www.aprh.pt/rgci/pdf/rgci-383_Ferreira.pdf | DOI:10.5894/rgci383

\title{
Impact of harvest by humans on mussel populations around Easter*
}

\section{Impacto da apanha bumana nas populações de Mexilhão no período da Páscoa}

\author{
Ana Margarida Ferreira ${ }^{1}$, Sónia Seixas ${ }^{\circledR, 2,3}$, Andreia Rijo ${ }^{1}$, Sara Faria ${ }^{1}$, Vânia Fialho ${ }^{1}$
}

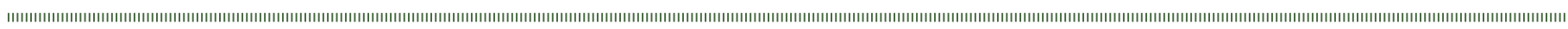

\begin{abstract}
The current macroeconomic scenario has subjected Portuguese coastal areas to greater human pressure caused by the ever-increasing shellfish harvest. Every year on Holy Friday, hundreds of people make their way to coastal areas and frantically capture hundreds of bags worth of mussels in a short amount of time. It causes not just inevitable and profound changes to the intertidal zone, but also slows down its recovery. In 2010 Cascais Municipality (CM) was made aware of this problem and in 2011 and 2012 released a general awareness campaign entitled "In Easter who pays is the mussel". More than just providing a legal perspective, the goal was to test the impact of said campaign in Meixilhoeiro's mussel beds. Biological data sampling in "Mexilhoeiro" was conducted over a three-year period, from 2010 to 2012. In 2010 there was no awareness campaign but sampling was done after Holy Friday. In 2011 and 2012 it was done both after and before Holy Friday. The average length and coverage percentage of individuals in rocks were recorded. The subsequent graphical analysis indicated that the average coverage percentage of mussels had been decreasing over the years. However a positive sign was recorded in after the 2012 awareness campaign, when the average length of individuals showed an increase. This could mean a reduction in harvesting during Holy Friday. Results suggest that awareness campaigns are effective measures in the immediate protection of marine resources, when supported by reinforcement in surveillance from fisheries protection authorities. For such improvements to persist, so must those efforts. Beachgoers in the summertime can have a detrimental impact on mussel bed size. Prohibiting recreational fishing will not suffice.
\end{abstract}

Keywords: Mytilus galloprovincialis, recreational harvest, Easter, Awareness campaign.

\section{RESUMO}

Actualmente, devido à conjuntura macro-económica, as zonas costeiras do país estão cada vez mais sujeitas à pressão antropogénica provocada pela apanha de organismos bivalves e marisco no geral. Desde 2010 que a Câmara Municipal de Cascais (CMC) tomou conhecimento da apanha desregrada destes recursos, principalmente no feriado de sexta-feira santa. Neste dia verifica-se a captura de vários quilos de mexilhäo (Mytilus galloprovincialis) por centenas de pessoas, o que provoca invariavelmente profundas perturbaçôes na zona Intertidal e torna a sua recuperação muito morosa. A CMC desenvolveu durante o ano de 2011 e 2012 a campanha de sensibilização "Na Páscoa quem paga éo Mexilhão!", que pretende alertar a população para esta problemática e informar acerca dos limites legais para a sua captura. O objectivo deste trabalho foi analisar o impacto da supracitada campanha de sensibilização nos bancos de mexilhão da zona do Mexilhoeiro (local preferencial de apanha). Realizaram-se amostragens no local durante três anos (2010 a 2012). Em 2010 não se realizou campanha de sensibilização e apenas foi realizada amostragem após a sexta-feira santa, no entanto realizaram-se amostragens em 2011 e 2012 antes e depois da sexta-feira santa.

\footnotetext{
@- Corresponding author

1 - Empresa Municipal de Ambiente de Cascais. Complexo Multiserviços, Estrada de Manique no1830 Alcoitāo. $2645-138$ Alcabideche. e-mail: Ferreira ana. ferreira@cascaisambiente.pt, Rijo andreia.rijo@cascaisambiente.pt, Fariasara.faria@cascaisambiente.pt, Fialhovania.fialho@cascaisambiente.pt

2 - Universidade Aberta.Rua Escola Politécnica, 147, Lisboa, Portugal. e-mail: sonia.seixas@uab.pt

3 - IMAR, CMA, University of Coimbra, Rua da Matemática, no 49, 3004-517 Coimbra, Portugal.
} 
Além da percentagem de cobertura dos individuos sobre a rocha, foi medido o comprimento médio dos indivíduos. A análise gráfica subsequente indicou que a percentagem de cobertura de mexilhão tem vindo a diminuir ao longo dos anos. No entanto, um sinal positivo foi registado em 2012, verificando-se um aumento do comprimento médio dos indivíduos, o que poderá indicar uma diminuição da apanha aquando o dia de sexta-feira santa. Os resultados apresentados sugerem que campanhas de sensibilização para informação do público em geral, acompanhadas por um reforço na fiscalização das actividates piscatórias, são efectivas na protecção imediata dos recursos marinhos. Porém, é necessário um esforço contínuo para a manutenção dos resultados alcançados, uma vez que, a simples visitaçáo massiva da zona no Verão pode ter impactos indesejados, que leva invariavelmente à diminuição da extenção dos bancos de mexilhão. Nestes casos a simples proibição da atividade piscatória não é suficiente.

Palavras-Chave: Mytilus galloprovincialis, apanha lúdica, Páscoa, Campanha de sensibilização.

\section{INTRODUCTION}

For many centuries mussels (Mytilus galloprovincialis) have been harvested along the Portuguese coast for human consumption, trade or use as bait. Nowadays, in the exposed rocky shores of central Portugal, Man plays a major predaceous role on the intertidal zone, harvesting mussels and goose barnacles (Pollicipes pollicipes).

The genus Mytilus is very common along European shorelines however the taxonomic status of the most abundant species (Mytilus edulis and Mytilus galloprovincialis) is very controversial. Modern biogeographic distribution of $M$. edulis and $M$. galloprovincialis appears related to water temperature. M. galloprovincialis is a warm-water form that occurs in the Mediterranean and extends northward to the coast of France and the United Kingdom (Lopez et al., 2002), so it is assumed that the Portuguese species of mussels is Mytilus galloprovincialis.

Various studies focusing on mussel harvesting in rocky shores have concluded that this activity causes a decline in population abundance, as well as a reduction in average size of individuals in that population (Rius \& Cabral, 2004; Rius et al., 2006). The consequences of harvesting mussels can have direct effects on other communities as they may provide a substratum for other organisms, which results in indirect effects on other species (Rius et al., 2006). On the other hand, recovery of intertidal communities from predatory effects can be very fast based on natural larvae recruitment or algae propagules that could have its origin in places with lighter human pressure (Hawkins et al., 1999).

According to the Christian calendar Easter is celebrated on the first Sunday after the first full moon during spring equinox, making it a moveable holiday. Tidal cycles are also synced with the moon cycle, so the highest of the high tides and the lowest of the low tides correspond to those full moons. These occurrences make Easter a great time for seafood harvest. Two reasons other than good tides help account for the Holy Friday harvest frenzy: it is a national holiday and religious tradition prevents most people from eating meat on this day. When combined, these three factors create a family tradition in Cascais where every family member joins in the mussel harvest in the morning, to consume it on the same day. Also, Cascais has easy access areas for seafood catching and transporting.

Overharvesting may lead to major changes in population structure and functioning and can seriously deplete stocks of intertidal organisms (Rius et al., 2006). A study conducted in Australia by Underwood \& Kennely (1990) suggests that recreational fishermen and seashore visitors can be responsible for density reductions on herbivorous and carnivorous fish as well as crabs, ascidians, gastropods (used as bait) and other rock-dwelling animals, rendering the structure and dynamics of coastal communities unbalanced.

Thompson et al. (2002) globally believe the harvesting severity has been increasing ever since the 1960s and predicted a continuous increase until the present time. As for mussels in Cascais council, Rius \& Cabral (2004) found a connection between less accessible places and individuals with longer shells and higher biomass, while places with easier access revealed the opposite, especially after the summer holidays. The same study suggests continuous mussel harvest in easily accessible places can cause mussel bed instability, as system equilibrium depends on the absence of regular human presence during wintertime.

Current macroeconomic conditions have subjected Portuguese coastal areas to greater human pressure, caused by the ever-increasing seashell harvest, as an alternative to fish during Holy Friday.

In 2010 Cascais Municipality (CM) was made aware of the unruly harvest of this marine resource on Holy Friday. Hundreds of people collecting bags of mussels in a short period of time (Figure 1) have caused profound changes in the intertidal zone, slowing down its recovery. Minimum harvest size ( $5 \mathrm{~cm}$ of shell length) and weight (2kg per person) was not being respected, and local authorities provided no surveillance whatsoever.

In 2011 and again in $2012 \mathrm{CM}$ released the "In Easter who pays is the mussel" awareness campaign, also to inform people of capture limitations under the law $(2 \mathrm{~kg}$ of mussel per person). This campaign was aimed at different targets: restaurants, professional fishermen, recreational fishermen and the population in general, with different timings.

For this study, possible negative impacts of concentrated harvest efforts on Holy Friday were investigated, both regarding coverage percentage and average length of individuals. We have also searched for positive effects of the awareness campaign on both factors.

\section{MATERIAL AND METHODS}

\subsection{Study area}

The area known has "Mexilhoeiro" (Figure 2) is located southwest of Cascais (38 41'37.99” N / 09'26'08.08” W), exposed to southern waves and easily accessible. The name comes from the extensive mussel bed always said to exist in this location (mussel = mexilhão). 


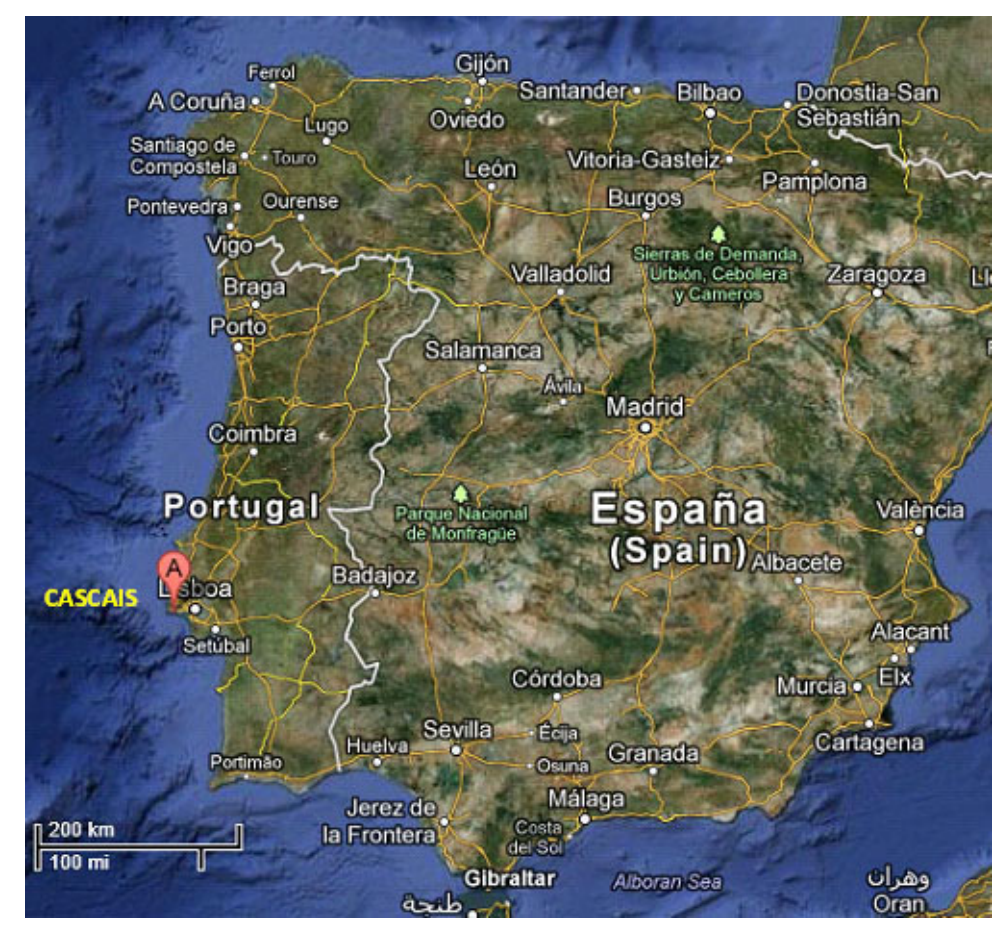

Figure 1. Map of Portugal with the Cascais council tagged (source: Google maps).

Figura 1. Mapa de Portugal com o concelho de Cascais assinalado (fonte: Google maps).
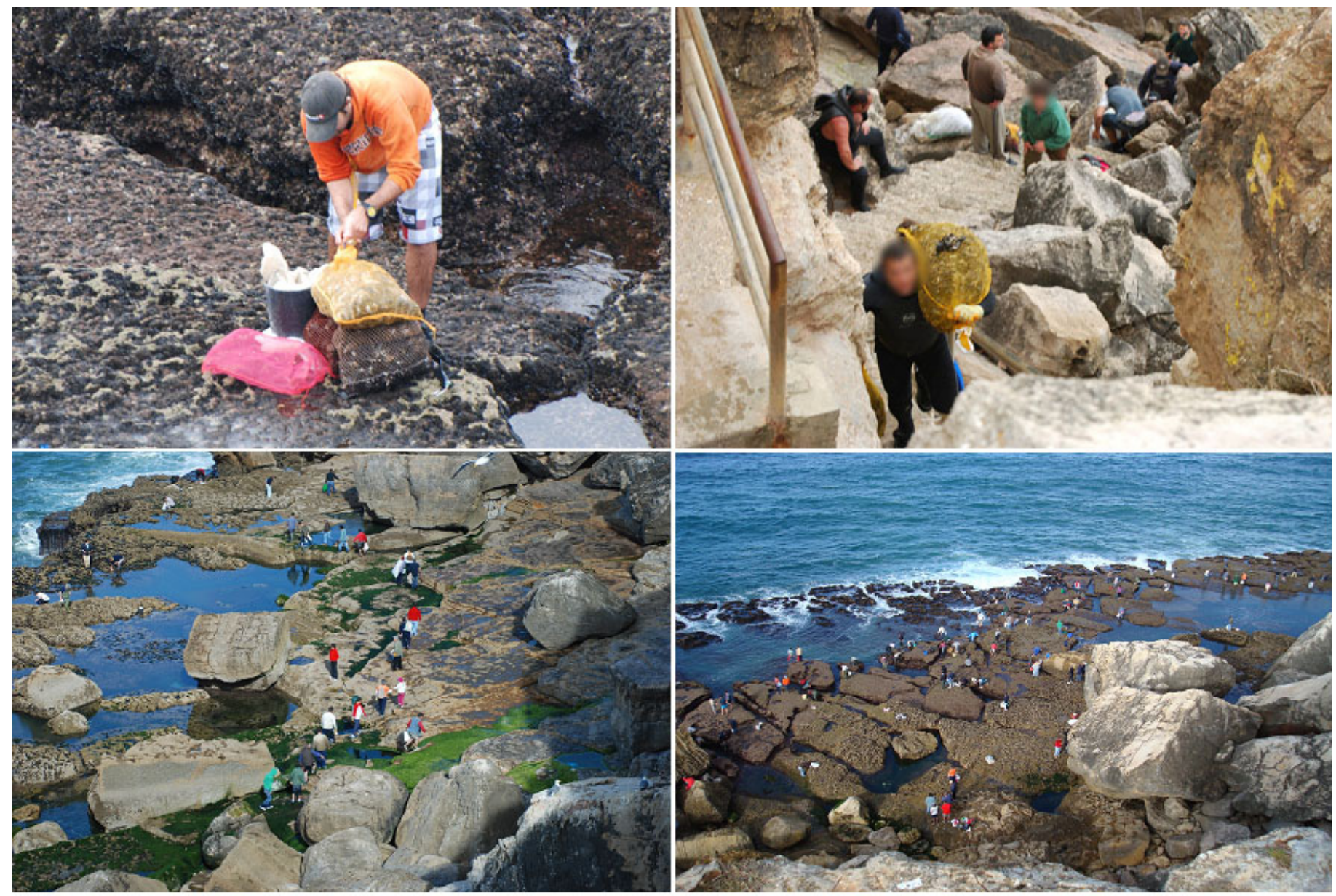

Figure 2. Photos by Miguel Lacerda, taken on Holy Friday 2010 (April 2) at Mexilhoeiro, Cascais.

Figura 2. Fotos de Miguel Lacerda tiradas na Sexta-feira Santa de 2010 (2 de Abril) no Mexilhoeiro, Cascais. 
Because of imminent danger caused by erosion in 2012, warning signs were placed on site informing visitors the area was closed. These signs, however, are often ignored and people still access the shore through a set of steps formed by rocks.

Two areas can be identified in the rocky platforms of "Mexilhoeiro" (Figure 3): Area A, with less human pressure, and not as exposed to waves in the summer. Ulva intestinalis exists here in great abundance; and Area B has higher human pressure because it is exposed to waves and its rock surface has cracks filled with mussels and goose barnacles. This area is only without water during very low tides, so people believe seafood caught here is good for human consumption as long as water quality remains good.

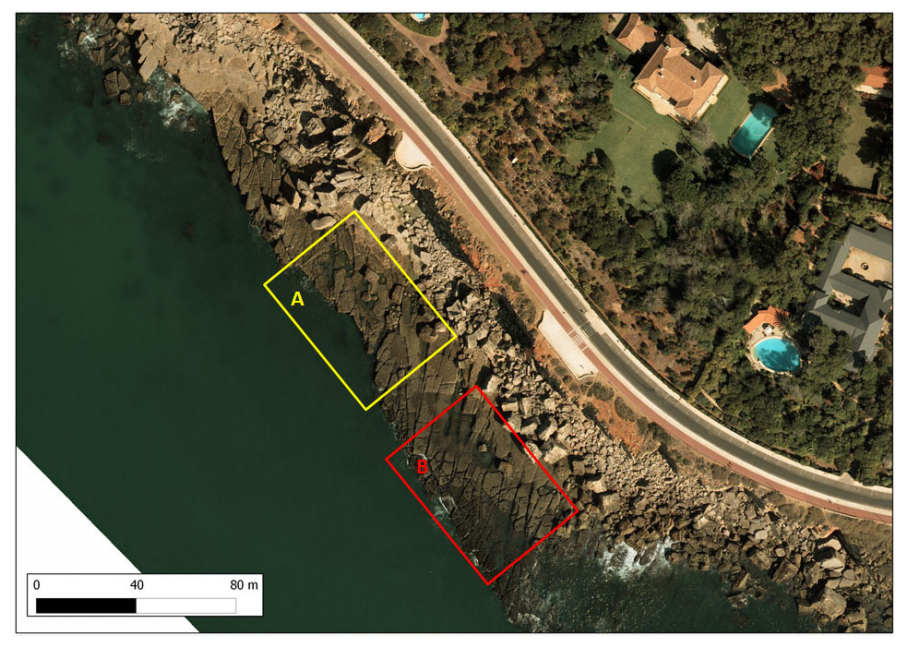

Figure 3. Sampling area in "Mexilhoeiro" (Cascais) on a scale of 1:1000; the two rectangles represent the two areas compared. The yellow rectangle represents area $\mathrm{A}$ and the red rectangle represents area $\mathrm{B}$ in a very low tide.

Figura 3. Área de amostragem no "Mexilhoeiro" (Cascais) numa escala de 1:1000; os dois retângulos representam as 2 áreas em comparaçâo. $O$ retângulo amarelo representa a área $A$ e o retângulo vermelho representa a área $B$.

\subsection{Sampling Methodology}

Sampling campaigns were conducted over a three-year period. In 2010 this was only possible after Easter while in following years $(2011,2012)$ sampling was conducted before and after the Easter period (Table 1), when adequate atmospheric conditions were found. In order to compare the density of mussel beds in both areas, mussel coverage percentage per square meter was recorded. Ten random 0.25 $\mathrm{m}^{2}$ string grid quadrat replicates were made in area A and B (as in Rius \& Cabral, 2004).

A calliper $(0.1 \mathrm{~mm}$ precision $)$ was used to record the average length of the larger axis of shells, to compare mussel shell length from both areas (A and B). Thirty random individual were selected from each area.

\subsection{Statistics Methodology}

A graphical exploratory analysis was conducted in order to compare the average coverage percentage of mussels per square meter in both areas and in different years. Several hypothesis tests followed. The same procedure was used to assess the average length of individuals.

Whenever statistical analysis was conducted for one variable (time or year) with two groups, the exploratory analysis was followed by a t-test or Mann-Whitney test (when data didn't obey normality and homocedastic assumptions) (Zar, 2009).

When statistical analysis was conducted for one variable (time) with three groups (years), the graphical analysis was followed by a Kruskal-Wallis test since data didn't obey normality and homocedastic assumptions (Zar, 2009). Because data dispersion recorded in each year is very high, a Mann-Whitney test was conducted to analyse the differences between those same years.

SPSS software (IBM SPSS Statistics V21) was used for the statistics methodology, with a 0.05 value of significance.

\subsection{Awareness campaign}

Communication campaign on the problem of intensive capture of mussels:

\section{a. Restaurants}

A letter was sent by the Municipality one month before Holy Friday addressed to major seafood restaurants in Cascais, informing about the dangers of buying nonregistered, non-depurated seafood (required for category $B$ mussels captured in this area).

\section{b. General population}

Media-promoted campaign a week before Holy Friday sharing some curiosities about mussels and the impact overharvesting has on the ecosystem. Furthermore, 1000 flyers were printed with information about this tradition, legal limitations and said negative impacts (Figure 4).

Table 1. Sampling days before and after the Campaign "In Easter who pays is the mussel".

Tabela 1. Dias de amostragem antes e depois da Campanha "Na Páscoa quem paga é o Mexilhão".

\begin{tabular}{cc|cc|cc|cc}
\cline { 3 - 7 } & \multicolumn{2}{c}{ Sampling date } & Tide level & Holy Friday & Tide level & Sampling date & Tide level \\
\hline & $\mathbf{2 0 1 0}$ & - & & $02-04-2010$ & 0.81 & $28-04-2010$ & 0.63 \\
$1^{\text {st }}$ year of Campaign & $\mathbf{2 0 1 1}$ & $18-04-2011$ & 0.53 & $22-04-2011$ & 1.12 & $20-05-2011$ & 0.95 \\
$2^{\text {nd }}$ year of Campaign & $\mathbf{2 0 1 2}$ & $20-03-2012$ & 1.02 & $06-04-2012$ & 0.60 & $09-04-2012$ & 0.66 \\
\hline
\end{tabular}



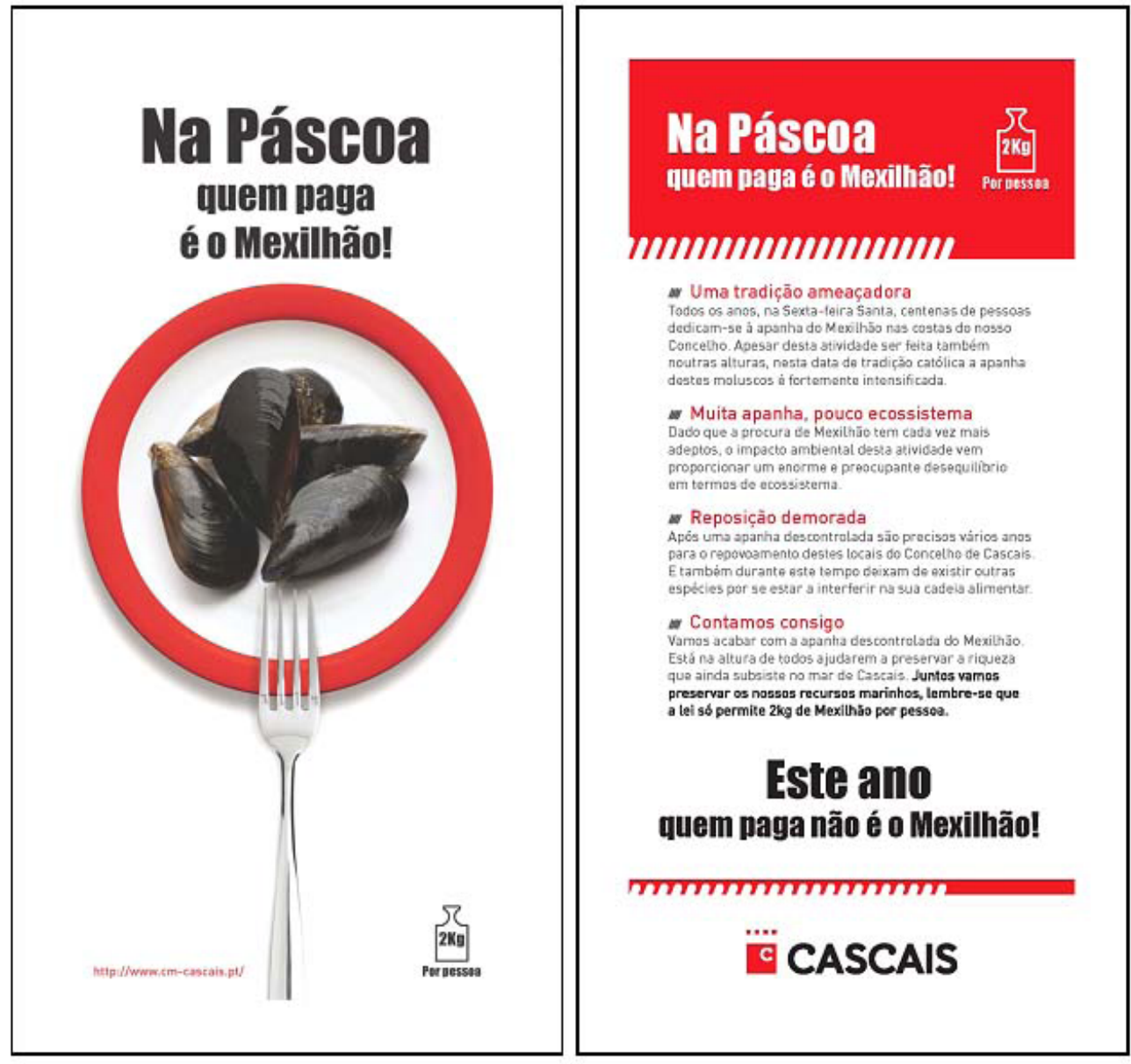

Figure 4. Campaign flyer "In Easter who pays is the mussel".

Figura 4. Folheto da Campanha "Na Páscoa quem paga é o Mexilhão".

Meixilhoeiro is one of the prime locations for this activity in Cascais. On Friday morning teams sporting t-shirts of the campaign handed out flyers and small $2 \mathrm{~kg}$ bags for mussel harvesting. They also showed people mussels with the minimum allowed length.

\subsection{Reinforced surveillance}

The success of this initiative was also made possible thanks to efforts by Maritime and Municipal Police forces. In "Mexilhoeiro" were 2 municipal police officers, while agents from the Maritime Police patrolled the coast. Technical teams were equipped with scales to weigh bags collected, when in doubt.

This surveillance effort of 2012 started one month before Easter and continued until the end of the year in throughout Cascais on every low tide $(<0.8 \mathrm{~m})$.

Each awareness campaign conducted had the support of 22 people between Maritime and Municipal Police forces, Municipal Technicians and volunteers.

\section{RESULTS}

Families who traditionally harvest mussels on Holy Friday acknowledged the information conveyed in the 2012 campaign, namely by using bags handed out to exemplify the $2 \mathrm{~kg}$ weight limit per person.
Professional fishermen present were informed of the campaign and their licenses checked. The number of illegal groups of fishermen who systematically capture more than $2 \mathrm{~kg} /$ person decreased in 2012. Only one apprehension was recorded during that year's campaign, having $11 \mathrm{~kg}$ of goose barnacles been returned to the sea by the Maritime Police. The legal limit is $0.5 \mathrm{~kg}$.

Another very positive aspect was the interest shown by TV stations, ensuring proper communication of legal limits for mussel and goose barnacle harvest, and informing people of how to help preserve coastal zones.

It is safe to say that at the end of the campaign human pressure in traditional harvest areas was not as intense. These general observations were confirmed by biological sampling and analyses conducted after Easter 2012.

\subsection{Average mussel coverage percentage}

In order to analyse the effectiveness of the Awareness Campaign in Mexilhoeiro, various hypothesis tests were conducted (Table 2) regarding the long-term (Year-to-year comparison) and short-term impact (comparisons within each year, before and after the campaign):

Graphical analysis of figure 5 indicates no shortterm impact differences before and after Holy Friday (notwithstanding the area or year analysed). The following statistical analysis confirms the graphical analysis (Table 2). 
Table 2. Summary of the statistical analysis performed on the short-term and long-term perspectives for mussel coverage percentage on a significance level of 0.05 .

Tabela 2. Sumário da análise estatística realizada numa perspetiva a curto e a longo prazo para a percentagem de cobertura a um nivel de significância de 0,05.

\begin{tabular}{|c|c|c|c|c|c|}
\hline & Null Hypotheses & \multirow{2}{*}{$\begin{array}{l}\text { Test value } \\
\mathrm{T}=0.732\end{array}$} & p-value & \\
\hline \multirow{6}{*}{ 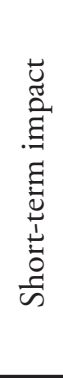 } & & $\mathrm{H}_{0}$ : Before 2011 = After 2011 & & 0.473 & Acceptance of $\mathrm{H}_{0}$ \\
\hline & Area A & & & & \\
\hline & & $\mathrm{H}_{0}:$ Before $2012=$ After 2012 & $\mathrm{~T}=0.495$ & 0.629 & Acceptance of $\mathrm{H}_{0}$ \\
\hline & & $\mathrm{H}_{0}$ : Before 2011 = After 2011 & $\mathrm{~T}=0.878$ & 0.391 & Acceptance of $\mathrm{H}_{0}$ \\
\hline & Area B & & & & \\
\hline & & $\mathrm{H}_{0}$ : Before 2012 = After 2012 & $\mathrm{U}=45.500$ & 0.760 & Acceptance of $\mathrm{H}_{0}$ \\
\hline \multirow{2}{*}{ 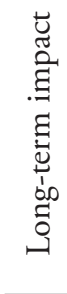 } & & $\mathrm{H}_{0}$ : before $2011=$ before 2012 & $\mathrm{U}=77.500$ & 0.001 & Rejection of $\mathbf{H}_{0}$ \\
\hline & & $\mathrm{H}_{0}$ : after $2010=$ after $2011=$ after 2012 & $\mathrm{H}=17.844$ & 0.000 & Rejection of $\mathbf{H}_{0}$ \\
\hline
\end{tabular}
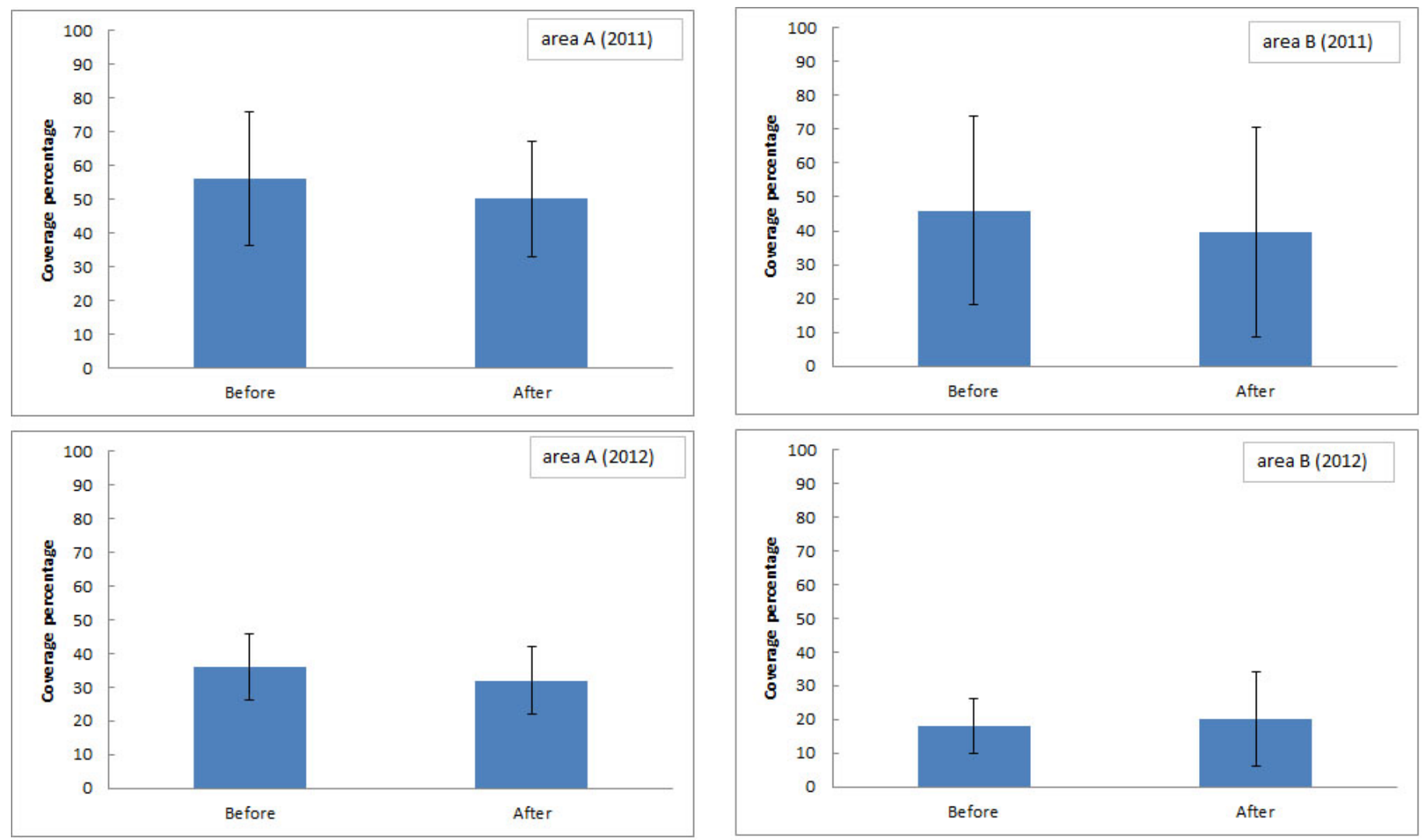

Figure 5. Graphical analysis of the average coverage percentage of mussels (before $v$ s after) Holy Friday in areas A and B, both in 2011 and 2012. The confidence intervals represent the standard deviation.

Figura 5. Análise gráfica da percentagem de cobertura média de mexilhão (antes vs depois) da Sexta-feira Santa nas áreas A e B e nos anos 2011 e 2012. Os intervalos de confiança representam o desvio padrão. 
Different results are obtained regarding long-term impact, as there is a significant decrease in average coverage percentages over the years before and after Holy Friday (Table 2 and Figure 6). This decrease is more evident in the year 2012, since this year shows significant differences with both 2010 and 2011 (Table 3).

Table 3. Results of the Mann-Whitney test for the comparison of mussel coverage percentage, between years and after the awareness Campaign.

Tabela 3. Resultados do teste de Mann-Whitney para a comparação das percentagens de cobertura de mexilhão entre ano, após a campanha de sensibilização.

\begin{tabular}{ccc}
\cline { 2 - 3 } & $\mathbf{U}$ & $\mathbf{p}$ \\
\hline 2010 vs 2011 & 130.000 & 0.060 \\
\hline 2010 vs 2012 & 47.500 & 0.000 \\
\hline 2011 vs 2012 & 111.000 & 0.017 \\
\hline
\end{tabular}

\subsection{Average mussle length}

Six hypotheses were tested for the mussel length data in order to analyse the effectiveness of the campaign in Mexilhoeiro area (Table 4) for long-term (Year-to-year comparison) and short-term impacts (comparisons within each year, before and after the campaign):

The first tests determined the differences in length of individuals between areas A and B, before and after 2011 and 2012 campaigns.

Graphical analysis (Figure 7) of the average mussel length before and after Holy Friday 2011 indicates a decrease in the mean length of individuals in both areas. However, standard deviation in both graphs did not reveal any extreme differences in these values. The Mann-Whitney and t-test (Table 4) conducted after the graphical analysis indicated significant differences in the average length of individuals of area A Before vs After Holy Friday. The same result was obtained for area B.

Figure 8 represents the same analysis for the 2012 Campaign and indicates a decrease in the average length of individuals of area A after Holy Friday. Individuals from area $\mathrm{B}$ on the other hand, recorded a small increase in the average length; however, the standard deviation bars are far apart revealing greater data dispersion. The following hypothesis tests (Table 4) indicated significant differences in average length of individuals in area A Before $v$ s After Holy Friday. As for area B, the Mann-Whitney test indicated no significant differences in average length of individuals Before vs After Holy Friday; however, the p-value is very close to the borderline and requires careful interpretation.

Regarding year-to-year differences (2011 vs 2012) before the Campaign, graphical analysis (Figure 9) did not reveal any differences in the average length of individuals, meaning that the initial conditions of the Awareness campaign were the same. Statistical tests (Table 4) confirmed this first analysis, as there were no significant differences in the mean shell length of individuals in "Mexilhoeiro".

After the Campaign, graphical analysis (Figure 9) showed a different result where in an increase in the average length of individuals from 2010 to 2012 seems to exist; on the other hand, standard deviation of 2010 and 2012 data is highly indicative of large data dispersion.

The Kruskal-Wallis test on data after the campaign did not detect any significant differences between the three years under analysis. However, the Mann-Whitney test detected differences between 2011 and 2012 (Table 5). These results suggest some positive long-term effects on the sampling area since the system seems to be reaching the mean length of individuals from 2010 (Mexilhoeiro).
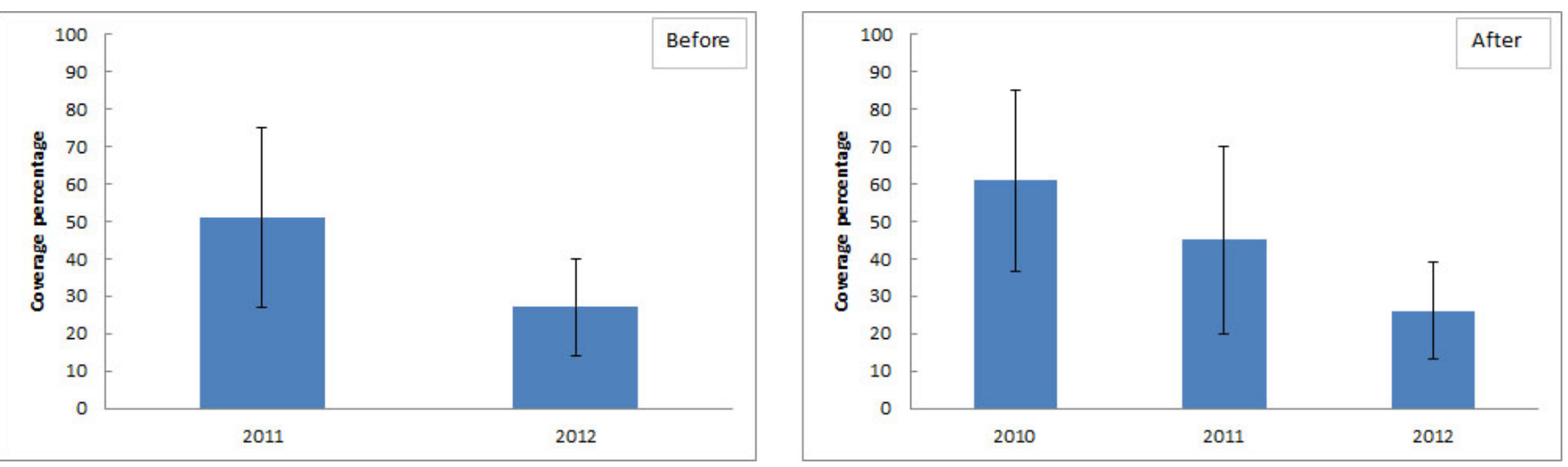

Figure 6. Graphical analysis of the average coverage percentage of mussels before Holy Friday (2011 vs 2012) and after this holiday (2010 vs 2011 vs 2012). The confidence intervals represent the standard deviation.

Figura 6. Análise gráfica da percentagem de cobertura média de mexilhão antes da Sexta-feira Santa (2011 vs 2012) e depois deste mesmo feriado (2010 vs 2011 vs 2012). 
Table 4. Summary of the statistical analysis performed on the short-term and long-term perspectives on the average length of mussels on a significance level of 0.05 .

Tabela 4. Sumário da análise estatística realizada numa perspetiva de curto e longo prazo para o comprimento médio dos mexilhöes a um nivel de significância de 0,05.

\begin{tabular}{|c|c|c|c|c|c|}
\hline & & Null Hypotheses & Test value & p-value & \\
\hline \multirow{5}{*}{ 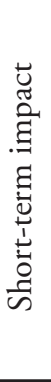 } & \multirow{3}{*}{ Area A } & $\mathrm{H}_{0}:$ Before 2011 = After 2011 & $\mathrm{U}=277.500$ & 0.011 & Rejection of $\mathrm{H}_{0}$ \\
\hline & & & & & \\
\hline & & $\mathrm{H}_{0}:$ Before $2012=$ After 2012 & $t=-4.010$ & 0.000 & Rejection of $\mathrm{H}_{0}$ \\
\hline & \multirow{2}{*}{ Area B } & $\mathrm{H}_{0}:$ Before 2011 = After 2011 & $\mathrm{t}=2.479$ & 0.020 & Rejection of $\mathbf{H}_{0}$ \\
\hline & & $\mathrm{H}_{0}$ : Before $2012=$ After 2012 & $\mathrm{U}=316.000$ & 0.048 & Acceptance of $\mathrm{H}_{0}$ \\
\hline \multirow{2}{*}{ 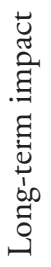 } & \multirow{2}{*}{$\begin{array}{c}\text { Between } \\
\text { Years }\end{array}$} & $\mathrm{H}_{0}$ : before 2011 = before 2012 & $\mathrm{U}=1612.000$ & 0.325 & Acceptance of $\mathrm{H}_{0}$ \\
\hline & & $\mathrm{H}_{0}:$ after $2010=$ after $2011=$ after 2012 & $\mathrm{H}=5.432$ & 0.067 & Acceptance of $\mathrm{H}_{0}$ \\
\hline
\end{tabular}

Table 5. Results of the Mann-Whitney test on the comparison of the average length of individuals, between years and after the awareness Campaign.

Tabela 5. Resultados do teste de Mann-Whitney na comparaçáo entre anos do comprimento médio dos individuos após a Campanha de Sensibilização.

\begin{tabular}{ccc}
\cline { 2 - 3 } & $\mathbf{U}$ & $\mathbf{P}$ \\
\hline 2010 vs 2011 & 1468.500 & 0.082 \\
\hline 2010 vs 2012 & 1675.500 & 0.515 \\
\hline 2011 vs 2012 & 1388.500 & 0.031 \\
\hline
\end{tabular}
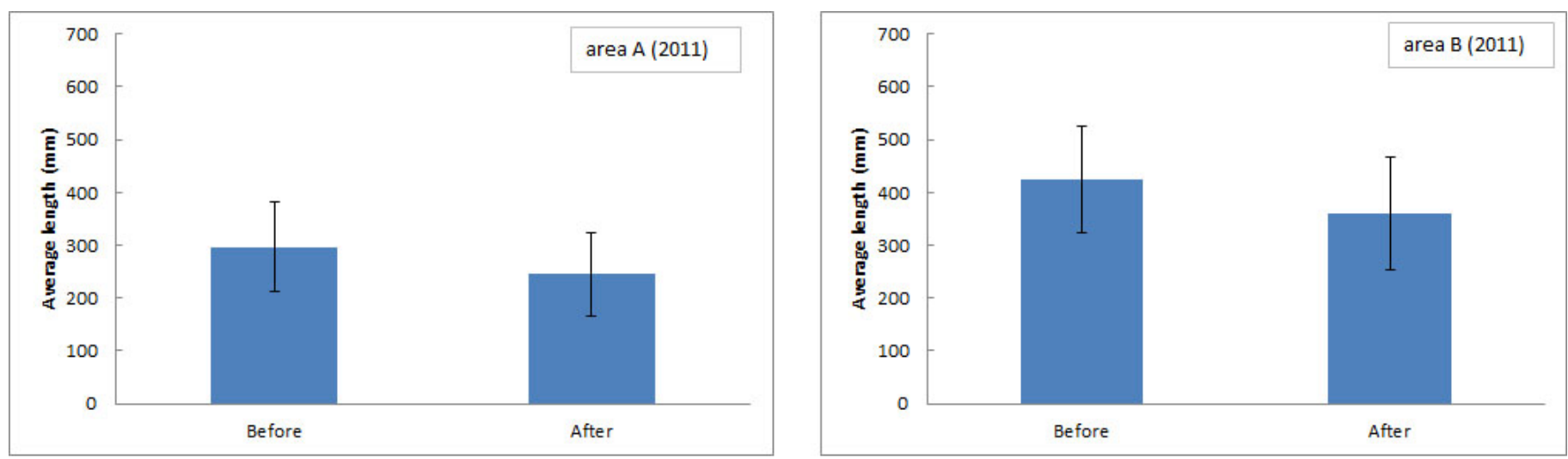

Figure 7. Graphical analysis of the mean length of individuals of area A and B (before vs after) in 2011. The confidence intervals represent the standard deviation.

Figura 7. Análise gráfica do comprimento médio dos individuos da Área A e B (antes vs depois) em 2011. Os intervalos de confiança representam $o$ desvio padrão. 

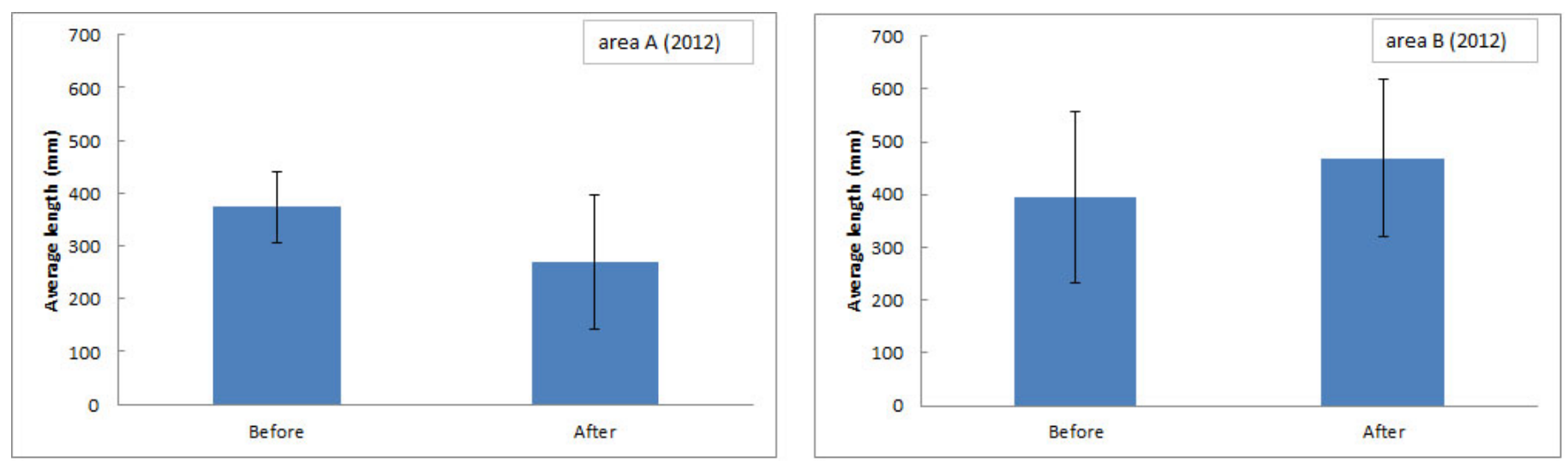

Figure 8. Graphical analysis of the mean length of individuals of area A and B (before $v$ after) in 2012. The confidence intervals represent the standard deviation.

Figura 8. Análise gráfica do comprimento médio dos indivíduos das áreas A e B (antes vs depois) em 2012. Os intervalos de confiança representam o desvio padrão.
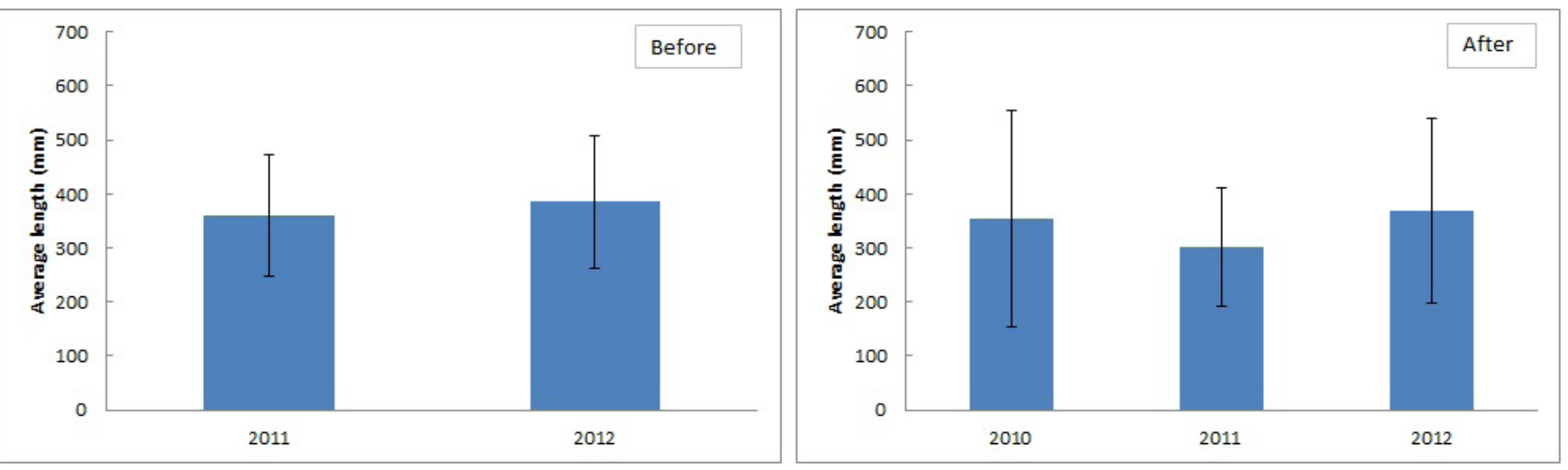

Figure 9. Graphical analysis of the mean length individuals before and after Easter from 2010 to 2012 . The confidence intervals represent the standard deviation.

Figura 9. Análise gráfica do comprimento médio dos individuos antes e depois da Páscoa desde 2010 até 2012. Os intervalos de confiança representam o desvio padrão.

\section{DISCUSSION}

Records show a decrease in coverage percentage of mussels in "Mexilhoeiro", Cascais, since 2010. Such decline was registered in both areas of "Mexilhoeiro" with different levels of human pressure, after Easter. Results clearly express the pressure to which the rocky shore is exposed, as mussel beds cannot recover its abundance within its natural cycle. This pressure is enhanced by existing efforts to catch larger individuals - the main contributors to population spawning events - selecting areas where they exist. Harvest, however, is done in bulk, capturing both small and large individuals (Rius et al., 2006). This fact occurs traditionally over a small window of time, mornings on Holy Friday, not allowing the system to readjust itself. Rius \& Cabral equally referred this very same behaviour in 2004 regarding the limited amount of time available to catch larger individuals located lower on the shore, because of tidal periods. Fishermen catch mussels in bulk during low tide, and then pick the larger from the smaller individuals, discarding the latter. This behaviour right before springtime could lead to a structural community problem as larger individuals - more fecund are harvested before their reproductive peak (Philippart et al., 2012, Rius et al., 2006). This means that along with the abrupt loss of biomass, individuals are collected without completing that year's reproduction cycle, reducing the number of mussel recruits every year, causing long-term effects. These observations are consistent with the study by Oliveira et al. (2011) in NW Portugal, which indicated a brief positive relationship between the intensity of human disturbance on rocky shores and the structure assemblage of mussel community. Patches suffering greater disturbance had difficulty in the re-establishment of $M$. galloprovincialis individuals. The same results were obtained by Rius et al., (2006) in South Africa, where a negative correlation was established between the density of humans as collectors and the cover percentage/average shell width of several sampled sites. As human collectors increase in density, coverage percentage of different sampled sites decreases as well as average shell width of individuals'. 
The trophic chain is also affected by this abrupt biomass decrease as predators have to double their efforts to find prey, and could migrate to other areas were food is more abundant (Real \& Caraco, 1986).

Short-term effects of the Awareness campaign "In Easter who pays is the Mussel" show no difference in terms of average coverage percentage of individuals before $v s$ after Holy Friday regardless of the year or area analysed (Figure 5 and Table 2). The Campaign seems to have no impact on this particular variable.

Long term-effects of the Campaign showed some statistical differences. There was a significant decrease in average coverage percentage of the mussel bed prior to the Campaign, between 2011 and 2012 (Figure 6 and Table 2). The same result was verified after the Campaign, and 2012 was the year of the most significant decrease in average coverage percentage (Figure 6 and Table 3). The awareness effort seems to have no effect on this variable in the long run. Further studies in this area are needed to confirm this analysis, as the current time period is very short.

The short-term effects of the Awareness campaign show different results in the average length of individuals, for areas $\mathrm{A}$ and $\mathrm{B}$ in both years. Area A shows no effect as there are no differences in the average length of individuals before and after Holy Friday, regardless of the year analysed (Table 4, Figure 8 and 9). Area B shows different results. In 2011 the tendency is the same as in area $\mathrm{A}$, with no differences recorded before and after the Campaign (Figure 7); in 2012, however, there are significant differences in the average length of individuals after Holy Friday (Table 4). Analysing the standard deviation of 2012 data for area B (Figure 8) we can see there is some data dispersion adding to this fact, the p-value of the Mann-Whitney test is in the borderline $(p=0.048)$, so it is possible that these results are due to the size of the sampling effort and need to be further validated with the continuation of the study.

In summary, the short-term effects of the Awareness campaign are very diminutive and can't be associated to the Campaign itself, as there were no significant differences recorded for the two variables under analysis (Average length of individuals and Average coverage percentage) for 2011 (no matter the area). In addition, 2012 results showed the same trend.

Long-term results are encouraging and show a positive tendency towards a recovery in population. The initial condition of the Campaign remained the same both in 2011 and 2012, as there were no significant differences in the average length of individuals for both years before Holy Friday (Table 4 and Figure 9).

The results after the Campaign are different. Length data dispersion for 2010 and 2012 is very high (Figure 9) so the Kruskal-Wallis test did not reveal any differences in that three-year period. The comparison between years (Table 5), however, minimized the effect of data dispersion revealing a significant increase of average length of individuals from 2011 to 2012, showing a population recovery back to 2010 levels.

In summary, long-term effects of the Awareness campaign seem to have a positive trend on the average length of individuals. Further studies are however necessary to confirm this hypothesis, as mussel populations are subjected to various numbers of environmental variables that have a significant impact on the long and short-term effects. The average coverage percentage results are consistent with this analysis, as time is required for mussel beds to recover their extent, with new recruits resulting from the increase in spawning biomass (individuals with a higher average length).

Regardless of the necessary additional investigation, one fact could have made the difference between 2011 and 2012: reinforced surveillance by authorities in "Mexilhoeiro", preventing mussel harvest in critical low tide periods, as well as barring access to "Mexilhoeiro" to decrease pressure caused by visitors. This pressure is not to be ignored. Trampling causes some shells to be fractured and causes relaxation of the byssus matrix. This makes individuals get easily taken by the waves, increasing the vulnerability of young individuals to the margin effect of a mussel bed, as well vulnerability to predation (Smith et al., 2008). In these cases, simply prohibiting harvest is not enough. Bertocci et al. (2012) obtained he same result in north of Portugal. The results of this study did not support a predictable direct effect of protection, as the total abundance and the abundance of larger individuals did not differ between the MPA (Marine Protected Areas - no fishing zone) and two other reference shores.

The fast recovery of mussel beds has been recorded in other studies. For example, in the Wadden Sea where natural or human pressure occurred (Dankers et al., 2001) there are records of extraordinary recoveries because of a good reproduction year which caused an increase from 170 ha to 1280 ha in one year (Dankers et al., 1999 in Dankers et al., 2001). It is therefore expected that a rapid increase in the cover percentage of mussel beds occur should access to these rocky shores remain difficult. Larger individuals that weren't caught in the springtime can produce a bigger amount of recruits (Addessi, 1994) that will gradually increase the mussel bed. Once trampling from visitors is minimized, this mussel bed can rapidly increase its size through larva production by these individuals, who will presumably settle near Mexilhoeiro.

Only by increasing environmental awareness with the general public can change the behaviour of the population regarding this specific tradition on Holy Friday. This is truer when economic activities are involved and conservation measures of living resources clash with a major source of income for families. This is why it is necessary to double the efforts of the campaign every year, in order to educate the youngest generation and adults.

These initial results need to be confirmed with continuing sampling in the following years. A higher degree of information by the general population was noticed, because of the awareness campaigns. The "In Easter who pays is the Mussel" campaign, along with reinforced surveillance by the authorities will lead to a more effective protection of marine resources.

\section{ACKNOWLEDGMENTS}

We would like to acknowledge Miguel Lacerda for raising awareness about the problem and for participating in 
the sampling surveys; Maritime and Municipal police for all their effort and cooperation with this campaign and Dr. Rui Teixeira for the English revision of the manuscript.

\section{REFERENCES}

Addessi, L. (1994) - Human disturbance and long-term changes on a rocky intertidal community. Ecological Applications, 4: 786-797. doi: 10.2307/1942008.

Bertocci, I.; Dominguez, R.; Freitas, C.; Sousa-Pinto, I. (2012) - Patterns of variation of intertidal species of commercial interest in the Parque Litoral Norte (north Portugal) MPA: Comparison with three reference shores. Marine Environmental Research, 77: 60-70. doi: 10.1016/j.marenvres.2012.02.003.

Dankers, N.; Brinkman, A.G.; Meijboom, A.; Dijkman, E. (2001) - Recovery of intertidal mussel beds in the waddensea: use of habitat maps in the management of the fishery. Hydrobiologia, 465:21-30. doi: 10.1023/ A: 1014592808410 .

Hawkins, S.J.; Allen, J.R.; Bray, S. (1999) - Restoration of temperate marine and coastal ecosystems: nudging nature. Aquatic Conservation: Marine and Freshwater Ecosystems, 9:23-46. doi: 10.1002/(SICI)1099-0755(199901/02).

Lopez, J.L.; Marina, A.; Vásquez, J.; Alvarez G. (2002) - A proteomic approach to the study of the marine mussels Mytilus edulis and M. galloprovincialis. Marine Biology, 141(2): 217-223. doi: 10.1007/s00227-002-0827-4.

Oliveira, J.P.; Bertocci I.; Weber, G.M.; Sousa-Pinto, I. (2011) - Type and timing of disturbance modify trajectories of recovery of rockpool assemblages at Aguda (NW Portugal). Journal of Experimental Marine Biology and Ecology, 399(2): 135-141. doi: 10.1016/j. jembe.2011.01.023.

Philippart, C.J.M.; Amaral, A.; Asmus, R.; van Bleijswijk, J.; Bremner, J.; Buchholz, F.; Cabanellas- Reboredo, M.; Catarino, D.; Cattrijsse, A.; Charles, F.; Comtet, T.; Cunha, A.; Deudero, S.; Duchêne, J.C.; Fraschetti, S.; Gentil, F.; Gittenberger, A.; Guizien, K.; Gonçalves, J.M.; Guarnieri, G.; Hendriks, I.; Hussel, B.; Pinheiro
Vieira, R.; Reijnen, B.T.; Sampaio, I.; Serrao, E.; Sousa Pinto, I.; Thiebaut, E.; Viard, F.; Zuur, A.F. (2012) Spatial synchronies in the seasonal occurrence of larvae of oysters (Crassostrea gigas) and mussels (Mytilus edulis/ galloprovincialis) in European coastal waters. Estuarine, Coastal and Shelf Science, 108:52-63. doi: 10.1016/j. ecss.2012.05.014.

Real, L.; Caraco, T. (1986) - Risk and foraging in Stochastic environments. Annual Review of Ecology and Systematics, 17:371-90. doi: 10.1146/annurev. es.17.110186.002103.

Rius, M.; Cabral, H. (2004) - Human harvesting of Mytilus galloprovincialis Lamarck, 1819, on the central coast of Portugal. Scientia Marina, 68(4):545-551. doi: 10.3989/ scimar.2004.68n4545.

Rius M.; Kaehler S.; McQuaid C. (2006) - The relationship between human exploitation pressure and condition of mussel population along the south coast of South Africa. South African Journal of Science (ISSN 0038-2353), 102:130-136, South Africa. Disponível em: http://eprints. ru.ac.za/357/1/sajs_kaehler_relationship_betw_human_ exploitation.pdf

Smith, J.R.; Fong, P.; Ambrose, R.F. (2008) - The impacts of human visitation on mussel bed communities along the California Coast: Are regulatory marine reserves effective in protecting these communities? Environmental Management, 41:599-612. doi: 10.1007/s00267-0079066-2.

Thompson, R.C.; Crowe T.P.; Hawkins, S.J. (2002) Rocky intertidal communities: past environmental changes, present status and predictions for the next 25 years. Environmental Conservation, 29(2):168-191. doi: $10.1017 /$ S0376892902000115.

Underwood, A.J.; Kennelly, S.J. (1990) - Pilot studies for designs of surveys of human disturbance of intertidal habitats in New South Wales. Australian Journal of Marine and Freshwater Research, 41 (1):165-173. doi:10.1071/ MF9900165.

Zar, J. (2009) - Biostatistical analysis. 5th ed., 960p., Prentice Hall, Englewood Cliffs, NJ, U.S.A. ISBN: 9780131008465 